\title{
Alu-repeat Polymorphism in the Tissue Plasminogen Activator Gene and Risks of Myocardial Infarction in Tunisian Population
}

\section{Raoudha Bahri' ${ }^{1}$, Awatef Msolly ${ }^{2 *}$ and Asma Kassab ${ }^{2}$}

${ }^{1}$ Laboratory of Human Genetics and Anthropology, Faculty of Pharmacy, Monastir, Tunisia

${ }^{2}$ Department of Biochemistry and Molecular Biology, Faculty of Pharmacy, Monastir, Tunisia

\begin{abstract}
This study aimed to determine whether $I / D$ polymorphism predispose to the development of $M I$ in Tunisia. 50 patients with coronary artery disease complicated by $\mathrm{Ml}$ and 70 healthy controls were analyzed. Quantitative analyses lipids are founded. DNA was isolated from blood samples. Polymorphisms were assessed by polymerase chain reaction method. Statistical differences between groups were determined by Chi-square test. Compared to controls, cases have significantly higher levels of total cholesterol, triglycerides and LDL-cholesterol and lower level of HDL-cholesterol. There are no significant differences between patients and controls in terms of allelic and genotypic frequencies. However, the frequency of the "l" allele is higher in cases which have 2 MI ( $p=0.0354)$. Additionally, a statistically significant association between diabetes, arterial high blood pressure, family history and cigarette smoking with $\mathrm{Ml}$ was founded $(\mathrm{p}<0.01)$. I/D polymorphism of $t-P A$ gene is not associated with $\mathrm{MI}$ in this sample of Tunisian population.
\end{abstract}

Keywords: Myocardial infarction; t-PA gene; I/D polymorphism

\section{Introduction}

Myocardial infarction (MI) is a coronary artery disease (CAD) caused by the degeneration of heart tissues as a result of blood clot formation in coronary arteries [1]. It represents one of the most important health problems in many nations worldwide [2].

Although the major risk factors of MI are environmental factors such as high blood pressure, hypercholesterolemia, diabetes and cigarette smoking, evidence is accumulating which suggest that genetic polymorphisms have been implicated to the disease progression $[3,4]$. Furthermore, MI is directly related to the thrombosis-fibrinolysis system which is regulated by factors involved either in clot formation and lysis [5]. Several gene polymorphisms of the fibrinolytic proteins and their cross regulators have been studied [6] and some studies founded that polymorphisms in genes encoding the components of thrombosis-fibrinolytic cascade may be a contributing factor in disease etiology by creating an imbalance between the two processes [7].

Tissue plasminogen activator $(t-P A)$ produced by endothelial cells is involved in the breakdown of fibrin clot by converting plasminogen into plasmin, which then leads to fibrinolysis [8]. The $t-P A$ protein encoded by $t-P A$ gene (PLAT) is the inducer of fibrinolysis. The increased enzyme activity causes hyper-fibrinolysis which might leads to excessive bleeding whereas it's decreased activity result in thrombosis. t-PA-antigen might therefore either play an important role in the development and progression of vascular disease, culminating in thromboembolic complications or death, or t-PA-antigen might just indicate the co-existence of confounders such as hypertension, insulin resistance, heart failure or ischemic heart disease, all of which can cause endothelial dysfunction and vascular injury [9]. Several studies founded that a common insertion of an Alu-repeat in the intron 8 of the gene is considered to be involved in plasma levels of $t-P A[8,10,11]$. In fact, the presence of one $I / D$ allele was associated with a $50 \%$ increase in risk of MI, whereas homozygous carriers had a two fold adjusted increase in risk, suggesting an association between the number of Alurepeats and arterial thrombosis $[5,12]$.

The aim of this study is to determine whether $I / D$ polymorphism on the PLAT gene predispose to the development of MI in a sample of Tunisian population.

\section{Materials and Methods}

\section{Study population}

We conducted a case-control study in 50 patients, age $49 \pm 6.25$ (years), with CAD complicated by MI (confirmed by coronary angiography) ascertained from the Department of Cardiology in Fattouma Bourguiba University Hospital Monastir, Tunisia. The control group included 70 healthy volunteers, age $57 \pm 8.37$ (years). All subjects participated in the study on a voluntary basis, were interviewed by the same interviewer. The study, in accordance with Helsinki Declaration, was reviewed and approved by the local ethics committee and included only individuals that agreed to participate after reading and signing a free and informed consent form.

\section{Laboratory measurements}

Quantitative analyses lipids are founded in controls and patients within $24 \mathrm{~h}$ from collection. Plasma levels of total cholesterol (TC), triglycerides (TG) and HDL-cholesterol (HDL-C) were measured by an enzymatic colorimetric assay (using a clinical system, Beckman instruments). LDL-cholesterol (LDL-C) concentrations were calculated by using the Friedewald formula [13].

Leukocyte DNA was extracted from blood samples by routine phenol-chloroform method and amplified by polymerase chain reaction (PCR) using oligonucleotide primers:

\section{5' primer: 5'GTAAGAGTTCCGTAACAGGACAGCT3'}

3' primer: 5'CCCCACCCTAGGAGAACTTCTCTTT3'

*Corresponding author: Awatef Msolly, Department of Biochemistry and Molecular Biology, Faculty of Pharmacy, Monastir 5000, Tunisia, Tel: 0021697867155; E-mail: awatefmsolly@gmail.com

Received January 25, 2016; Accepted February 02, 2016; Published February 05, 2016

Citation: Bahri R, Msolly A, Kassab A (2016) Alu-repeat Polymorphism in the Tissue Plasminogen Activator Gene and Risks of Myocardial Infarction in Tunisian Population. Med chem 6: 072-074. doi:10.4172/2161-0444.1000327

Copyright: ( 2016 Bahri R, et al. This is an open-access article distributed under the terms of the Creative Commons Attribution License, which permits unrestricted use, distribution, and reproduction in any medium, provided the original author and source are credited. 
Amplification was performed in an automated thermal cycler (Master cycler). The PCR conditions were $10 \mathrm{~min}$ for initial denaturation at $94^{\circ} \mathrm{C}, 30$ cycles at $94^{\circ} \mathrm{C}$ for $1 \mathrm{~min}$ for denaturation, 1 min at $60^{\circ} \mathrm{C}$ for annealing and $2 \mathrm{~min}$ at $73^{\circ} \mathrm{C}$ for extension, followed by $5 \mathrm{~min}$ at $72^{\circ} \mathrm{C}$ for final extension. The amplified product was digested with restriction enzyme. The gel visualizing system was used (Vilber Lourmat, France). The fragments were separated on a $2 \%$ agarose gel stained with ethidium bromide.

\section{Statistical analysis}

Allelic and genotypic frequencies were calculated by direct gene counting method. Lipid and plasma parameters measures were compared through the student's t-test. Chi-square test was used to determine if there are any significant differences in polymorphism frequencies in cases compared to control population.

\section{Results}

The distribution of the selected characteristics of MI cases and controls are presented in Table 1. The statistical comparison between them showed a significant difference in terms of frequency of diabetes, arterial hypertension and family myocardial infarction history $(\mathrm{p}<0.01)$. Compared to controls, cases had significant higher levels of TC, TG, LDL-C and lower levels of HDL-C (Table 1).

Different genotypes of PLAT gene in cases and controls were identified in electrophoresis patterns of PCR fragments (Figure 1). The two groups showed no significant difference in terms of allele frequency $(\mathrm{p}=0.143)$ and genotype frequency $(\mathrm{p}=0.154)$ (Table 2). Therefore, the genotype frequency of myocardial infarction cases was $0.24 \%$ homozygotes $I / I, 0.32 \%$ homozygotes $D / D$ and $0.44 \%$ heterozygotes $I / D$, controls showed $0.27 \% I / I, 0.21 \% D / D$ and $0.51 \% I / D$.

The distribution of allele frequency of PLAT gene according to MI number for each patient is given in Table 3 . The frequency of the allele "I" is higher in cases which have $2 \mathrm{MI}(\mathrm{p}=0.0354)$.

\section{Discussion}

This work focused on the relation between the polymorphism of

\begin{tabular}{|l|l|l|l|}
\hline- & Cases $(\mathrm{n}=50)$ & Controls $(\mathrm{n}=70)$ & $\mathbf{P}$ \\
\hline Age (Mean $\mathbf{5}$ SD) & $49 \pm 6.25$ & $57 \pm 8.37$ & 0.115 \\
\hline Smoking (n) & 39 & 25 & 0.0124 \\
\hline Diabetes (n) & 25 & 5 & $<0.01$ \\
\hline Arterial hypertension (n) & 23 & 8 & $<0.01$ \\
\hline Family history (n) & 20 & 6 & $<0.01$ \\
\hline TC $(\mathrm{mmol} / \mathrm{L})$ & $4.62 \pm 0.91$ & $4.01 \pm 0.46$ & $<0.001$ \\
\hline TG $(\mathrm{mmol} / \mathrm{L})$ & $1.76 \pm 0.77$ & $0.78 \pm 0.18$ & $<0.001$ \\
\hline HDL-C $(\mathrm{mmol} / \mathrm{L})$ & $0.92 \pm 0.26$ & $1.07 \pm 0.12$ & $<0.001$ \\
\hline LDL-C $(\mathrm{mmol} / \mathrm{L})$ & $2.95 \pm 0.86$ & $2.57 \pm 0.44$ & $<0.01$ \\
\hline
\end{tabular}

\section{SD: Standard deviation}

Table 1: Selected characteristics of myocardial infarction cases and controls and lipid levels of the study population.

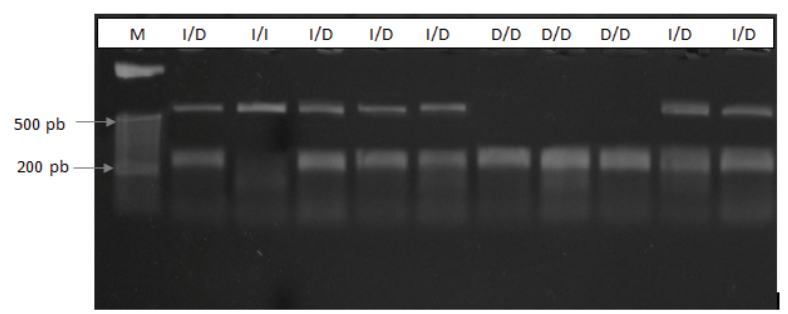

Figure 1: Electrophoresis patterns of PCR fragments for detection of PLAT I/D polymorphism.

\begin{tabular}{|l|c|c|c|}
\hline & Cases $\mathbf{( n = 5 0 )}$ & Controls $(\mathbf{n = 7 0 )}$ & $\mathbf{P}$ \\
\hline Allele frequency & & & \\
\hline I & 0.46 & 0.52 & 0.143 \\
\hline D & 0.54 & 0.47 & \\
\hline Genotype frequency & & & \\
\hline I/I, n (\%) & $12(0.24 \%)$ & $19(0.27 \%)$ & 0.154 \\
\hline I/D, n (\%) & $22(0.44 \%)$ & $36(0.51 \%)$ & \\
\hline D/D, n (\%) & $16(0.32 \%)$ & $15(0.21 \%)$ & \\
\hline
\end{tabular}

Table 2: Allele and genotype frequencies of cases and controls.

\begin{tabular}{|c|c|c|c|}
\hline \multirow[t]{2}{*}{ Allele } & \multicolumn{2}{|c|}{ Myocardial infraction number (N) } & \multirow[t]{2}{*}{$\mathbf{P}$} \\
\hline & $\mathbf{N}=1$ (19 Cases) & $\mathbf{N}=\mathbf{2}$ (31 Cases) & \\
\hline I/I & $4(0.210)$ & $8(0.258)$ & 0.0354 \\
\hline I/D & $6(0.315)$ & $16(0.516)$ & \\
\hline$D / D$ & $9(0.473)$ & $7(0.220)$ & \\
\hline
\end{tabular}

Table 3: Allele frequency according to myocardial infarction number.

PLAT gene and MI disease in Tunisian population. Several studies have investigated the regulating role of $t-P A$ in the degradation of the thrombus and founded that the protein appears to activate the transformation of plasminogen to plasmin, which digests the fibrin clot $[14,15]$. The $I / D$ polymorphism in the gene coding for $t-P A$ was associated with an increased or decreased levels in serum $t$ - $P A$. Further, the homozygous genotype $I / I$ of the $t-P A$ gene was associated with a higher risk of MI [16]. In this study, we found no significant differences between the two groups in terms of allelic and genotypic frequencies. Our results are contradictory to findings reported by van der Bom et al. [13] in which the authors founded that $I / I$ genotype was increased of twice in cases group, but they are consistent with results from others studies. In fact, Steed et al. [17] have founded that cases and controls was relatively similar in term of frequency of "I" allele $(0.57 \%$ vs $0.58 \%$, respectively) and no association between $I / D$ polymorphism and MI have been noted ( $>0.05)$. Furthermore, Hooper et al. [18] founded that the frequencies of " $I$ " allele was $0.37 \%$ in cases and $0.44 \%$ in controls. Moreover, in a recent meta-analysis included seven studies which investigated the relationship between $t-P A I / D$ polymorphism and $\mathrm{MI}$, the authors suggests that the polymorphism showed no consistent association with MI [19].

However, in our study we found that $I / I$ and $I / D$ genotype frequencies have a significant increase in patients with two MI compared to patients with one MI ( $\mathrm{p}=0.0354)$, which may be explained by the impact of the two genotypes on $t-P A$ enzymatic activity.

In terms of lipid levels, plasma TC, LDL-C and TG were raised in the disease group whereas HDL-C was reduced. Interestingly total plasma cholesterol did not discriminate between cases and controls as in other European countries [20]. Multiple regression analysis confirmed the independent predictive role for all of the above mentioned lipid parameters [21,22].

In addition, we have noted a statistically significant association between the environmental factors, including diabetes, arterial high blood pressure, family history and cigarette smoking with MI. This latter result confirms previous association studies where $t-P A$ protein expression was found to be influenced by environmental factors [7,18,23-25].

A discrepant findings support the idea that MI is a multifactorial disease which may be the result of "gene-environment" interaction.

In interpreting the results from our current study, several potential limitations need to be considered. A potential concern is the study sample size that is relatively small. Another potential limitation of our 
study concerns use of hospital-based cases and controls. While every effort was made to include all cases admitted to the study hospitals, we did not attempt to ascertain patients who may not have come to this hospital. Therefore, the generalizability of our results may be limited because of the hospital-based study design. Additionnally, controls has a higher average age than the MI patients, a study sample with a quite comparative age need to be considered.

Despite these limitations, the study contributes to our understanding of MI in this population and provides some of the first data on relationship between t-PA polymorphism and MI in Tunisia.

\section{Conclusions}

Our results demonstrated that the risk allele "I" was not found to be associated with MI. However, $I / I$ and $I / D$ genotype frequencies have a significant increase in patients with two MI compared to patients with one MI. Additionally, we noted a statistically significant association between the environmental factors and MI.

\section{Acknowledgements}

We would thank all contributors from the Cardiology Department of Fattouma Bourguiba Hospital, Monastir, Tunisia.

\section{References}

1. Joshi $P$, Islam $S$, Pais $P$, Reddy $S$, Dorairaj $P$, et al. (2007) Risk factors for early myocardial infarction in South Asians compared with individuals in other countries. JAMA 297: 286-294.

2. Abd El-Aziz TA, Rezk NA (2015) Relation of PAl-1 and TPA genes polymorphisms to acute myocardial infarction and its outcomes in Egyptian patients. Cell Biochem Biophys 71: 227-234.

3. Margaglione M, Cappucci G, Colaizzo D, Giuliani N, Vecchione G, et al. (1998) The PAl-1 gene locus $4 \mathrm{G} / 5 \mathrm{G}$ polymorphism is associated with a family history of coronary artery disease. Arterioscler Thromb Vasc Biol 18: 152-156.

4. Crainich P, Jenny NS, Tang Z, Arnold AM, Kuller LH, et al. (2003) Lack of association of the plasminogen activator inhibitor-1 4G/5G promoter polymorphism with cardiovascular disease in the elderly. $\mathrm{J}$ Thromb Haemost 1: 1799-1804.

5. Voetsch B, Loscalzo J (2004) Genetic determinants of arterial thrombosis Arterioscler Thromb Vasc Biol 24: 216-229.

6. de Lange M, Snieder H, Ariens RA, Spector TD, Grant PJ (2001) The genetics of haemostasis: a twin study. Lancet 357: 101-105.

7. Ahmed W, Malik M, Saeed I, Khan AA, Sadeque A, et al. (2011) Role of tissue plasminogen activator and plasminogen activator inhibitor polymorphism in myocardial infarction. Mol Biol Rep 38: 2541-2548.

8. Robinson SD, Ludlam CA, Boon NA, Newby DE (2006) Tissue plasminogen activator genetic polymorphisms do not influence tissue plasminogen activator release in patients with coronary heart disease. J Thromb Haemost 4: 22622269.

9. Freynhofer MK, Draxler DF, Gruber SC, Bruno V, Hochtl T, et al. (2013) Endogenous t-PA-antigen is an independent predictor of adverse cardiovascular events and all-cause death in patients with atrial fibrillation. J Thromb Haemost 11: 1069-1077.

10. Ridker PM, Baker MT, Hennekens CH, Stampfer MJ, Vaughan DE (1997) Alurepeat polymorphism in the gene coding for tissue-type plasminogen activator (t-PA) and risks of myocardial infarction among middle-aged men. Arterioscler Thromb Vasc Biol 17: 1687-1690.

11. Nakazawa I, Nakajiima T, Ishigami T, Umemura S, Emi M (2001) Linkage disequilibrium and haplotype analysis among eight novel single-nucleotide polymorphisms in the human tissue-type plasminogen activator (t-PA) gene. $\mathrm{J}$ Hum Genet 46: 367-371.

12. van der Bom JG, de Knijff P, Haverkate F, Bots ML, Meijer P, et al. (1997)
Tissue plasminogen activator and risk of myocardial infarction. The Rotterdam Study. Circulation 95: 2623-2627.

13. Friedewald WT, Levy RI, Fredrickson DS (1972) Estimation of the concentration of low-density lipoprotein cholesterol in plasma, without use of the preparative ultracentrifuge. Clin Chem 18: 499-502.

14. Shoji M, Tsutaya S, Oshikata C, Yasujima M (2003) Lack of association of 4G/5G polymorphism in plasminogen activator inhibitor-1 gene with stroke. Int Congr Ser 1251: 105-109.

15. Soysal D, Emuroglu T, Biceroglu S, Cevik C, Ulusoy S, et al. (2006) The association of Plasma PAl-1 and t-PA antigen concentrations with related cardiac risk factors in their first-degree relatives. Turkiye Klinikleri J Cardiovasc Sci 18: 4-12.

16. Jood K, Ladenvall P, Tjarnlund-Wolf A, Ladenvall C, Andersson M, et al. (2005) Fibrinolytic gene polymorphism and ischemic stroke. Stroke 36: 2077-2081.

17. Steeds R, Adams M, Smith P, Channer K, Samani NJ (1998) Distribution of tissue Plasminogen Activator (t-PA) Insertion/Deletion polymorphism in myocardial infarction and control subjects. Thromb Haemost 79: 980-984.

18. Hooper WC, Lally C, Austin H, Renshaw M, Dilley A, et al. (2000) The role of the t-PA I/D and PAI-1 4G/5G polymorphisms in African-American adults with a diagnosis of myocardial infarction or venous thromboembolism. Thromb Res 99: 223-230.

19. Gong LL, Peng JH, Han FF, Zhu J, Fang LH, et al. (2012) Association of tissue plasminogen activator and plasminogen activator inhibitor polymorphism with myocardial infarction: a meta-analysis. Thromb Res 130: e43-51.

20. Masana L, Febrer G, Cavanna J, Baroni MG, Marz W, et al. (2001) Common genetic variants that relate to disorders of lipid transport in Spanish subjects with premature coronary artery disease. Clin Sci (Lond) 100: 183-190.

21. Elisaf MS, Siamopoulos KC, Tselegarides TJ, Bairaktari ETh, Goudevenos JA et al. (1997) Lipid abnormalities in Greek patients with coronary artery disease. Int J Cardiol 59: 177-184.

22. Baroni MG, Berni A, Romeo S, Arca M, Tesorio T, et al. (2003) Genetic study of common variants at the Apo E, Apo Al, Apo CIII, Apo B, lipoprotein lipase (LPL) and hepatic lipase (LIPC) genes and coronary artery disease (CAD): variation in LIPC gene associates with clinical outcomes in patients with established CAD. BMC Med Genet 4: 8 .

23. Hafer-Macko CE, Ivey FM, Sorkin JD, Macko RF (2007) Microvascular tissue plasminogen activator is reduced in diabetic neuropathy. Neurology 69: 268-274.

24. Ismail J, Jafar TH, Jafary FH, White F, Faruqui AM, et al. (2004) Risk factors for non-fatal myocardial infarction in young South Asian adults. Heart 90: 259-263.

25. Jafary MH, Samad A, Ishaq M, Jawaid SA, Ahmad M, et al. (2007) Profile of acute myocardial infarction (AMI) in Pakistan. Pak J Med Sci 23: 485-489. 